\title{
Science, Technology, Engineering and Mathematics (STEM): A Case Study of Zimbabwe's Educational Approach to Industrialisation
}

\author{
Hardy Chitate ${ }^{1, *}$ \\ ${ }^{1}$ Department of Curriculum and Arts Education, Faculty of Education, University of Zimbabwe, Harare, Zimbabwe \\ *Correspondence: Department of Curriculum and Arts Education, Faculty of Education, University of Zimbabwe, \\ Harare, Zimbabwe. E-mail: hchitate@yahoo.co.uk
}

Received: August 12, 2016

Accepted: September 1, $2016 \quad$ Online Published: September 22, 2016

doi:10.5430/wje.v6n5p27

URL: http://dx.doi.org/10.5430/wje.v6n5p27

\begin{abstract}
One of the fundamental pre-requisites for Industrialisation is its stupendous availability, in a country of skilled-manpower. In this regard, Zimbabwe has sought to leverage human resources, such as these, in order to accelerate the process of socio-economic transformation. In March 2012, for example, the Government of Zimbabwe (GoZ) pronounced the 'Second Science, Technology and Innovation Policy' framework, which provided the two Ministries of Primary and Secondary Education and Higher and Tertiary Education, Science and Technology Development with the opportunity to implement the relevant spellings out of that policy document. The former launched an update review of the national curriculum, in 2014, which culminated, in the crafting of the Zimbabwe Education Blueprint (2015-2022). That education-design plan has many facets. Chief among them is a deliberate emphasis on the teaching of Science, Technology, Engineering and Mathematics, subjects that are now known popularly by the acronym 'STEM'. Classroom instruction, in those disciplines is meant to empower students with the cutting-edge skills that should see them participate actively, in both the local and global economies. The latter Ministry has rolled out the new STEM curriculum at the Advanced level, in January 2016. Through documentation analysis, this paper, therefore, attempts to unpack the new curricular innovation (STEM), that Zimbabwe has devised most recently as one of her very best policy strategies towards achieving industrial development, in the foreseeable future.
\end{abstract}

Keywords: curriculum; education and training; industrialisation; innovation; vocational and technical skills

\section{Introduction}

The turn of the century made Industrialisation the Holy Grail of many African countries, including Zimbabwe. For instance, the former chair of the Southern Africa Development Community (SADC) and the African Union (AU), His Excellency, the President and the Commander-in-Chief of the Defence Forces of the Republic of Zimbabwe, Comrade Robert Gabriel Mugabe, has envisaged the full Industrialisation of the continent by the year 2063. Consequently, regional groupings, such as SADC to, which Zimbabwe is a member state, are, in the process of drawing up elaborate roadmaps for economic development. To date, SADC has produced "a draft Regional Industrialisation Strategy and Roadmap that provides a framework for major economic and technological transformations at the national and regional levels within the context of deepening regional integration" (Ngwawi, 2015: 1). The primary focus of this strategy, whose chief aim is to exploit the comparative and competitive advantages of the region, is the ultimate attainment of Industrialisation, regional integration and economic competitiveness (Ngwawi, 2015).

To complement the SADC industrial initiative, the Government of Zimbabwe enunciated, in 2013, a new five-year economic blueprint called, "Zimbabwe Agenda for Sustainable Socio-Economic Transformation (October 2013-December 2018)", in short, Zim Asset with a vision, "Towards an Empowered Society and a Growing Economy.” In the words of Mugabe (2013: 1) "Zim Asset was crafted to achieve sustainable development and social equity anchored on indigenization, empowerment and employment creation, which will be largely propelled by the judicious exploitation of the country's abundant human and material resources.” The results-based agenda seeks to stimulate economic growth and the creation of wealth through its four strategic clusters, namely: "Food, Security, and Nutrition", "Social Services and Poverty Reduction", "Infrastructure and Utilities" as well as "Value Addition 
and Beneficiation”. The constraints of space do not permit a full examination of the above mentioned clusters. However, what is of most particular interest, in this academic discourse is to show how Zimbabwe has attempted to use education as an instrument for change of the "Social Services and Poverty Reduction" cluster to achieve her economic goals. The climax of the paper is an assessment of the potential challenges, prospects and benefits of that new developmental trajectory.

\subsection{Education Development, in the Post-Independent Zimbabwe}

The colonial epoch, in Zimbabwe from 1890 to 1979 witnessed the development of an education system that was elitist, in its deliberate bias; and was marked by exclusively limited access and facilities, as well as lack of relevance. It was against this background, combined with the pressing socio-economic demands of the Zimbabweans, which triggered the need for radical change, in education when the country eventually won political freedom from the then white-minority British colonial masters on the $18^{\text {th }}$ of April 1980. The first decade of political Independence, therefore, saw the main thrust of the new nation's post-colonial re-construction efforts being directed at the mass-improvement of educational access and equity, together with bringing the content, methods and assessment of education, in line with the existing African conditions, the postulate of national Independence and the imperatives of balanced economic development. The Education Secretary Report (1980-1987) quoted, in Nziramasanga (1999: 9), for example, notes:

In 1979, there were 2401 primary schools enrolling 81958 pupils learning in segregated schools, but ten years later primary schools had increased to 4 504, enrolling in excess of 2274178 pupils. At secondary school level, there were 177 schools in 1979 with a student population of 66 215. Ten years later, the secondary schools had increased to 1502 with an enrolment of 695882 students.

The net-result of the Government's educational policy intervention measures has been the development of a strong human resource base, which gives Zimbabwe a comparative advantage over regional and other international countries (Zim Asset, 2013). At present, the country has a staggering literacy level of ninety-two percent, which ranks the highest, in Africa. Zimbabwe, therefore, has every reason to look at her many highly academically-qualified citizens who are working, in foreign countries today with evident pride. Some of these workers occupy jobs, in companies or organisations associated with the commanding heights, in the economies of those countries.

Notwithstanding the seemingly impressive achievements cited above, the Government of Zimbabwe still went ahead with reviewing critically the newly existing system of education that it had established shortly after attaining political Independence, in 1980. It appointed a Commission on the $2^{\text {nd }}$ of January 1998 headed by Dr Caiphas Tizanarwo Nziramasanga, a senior research fellow at the University of Zimbabwe, to inquire into and report on the country's education and training. The Presidential Commission of Inquiry into Education and Training (CEIT) as it is formally called carried out the said investigation against:

The background of ... [the] phenomenal changes ... [that had taken place in the country's education system since Independence] and the pressures of the technological $21^{\text {st }}$ Century. The Inquiry into Education had to be extensive and intensive and, therefore, was targeted at all levels of education and training. The greatest part of the inquiry was done in Zimbabwe and the remainder were visits to 13 carefully selected countries to study only specific issues such as technology, vocational education, and programmes relating to disability ... education (Nziramasanga, 2014: 1-2).

In its final, wide-ranging report, the Commission observed that the educational system for Zimbabwe was largely academic. It was, therefore, perceived to be out of tune with the demands of the twenty-first Century Digital Age. Chere (2015: 7) agrees: The present curriculum

...is both outdated and incompatible with the factual realities obtaining in our country today. [It]...only caters for the academically gifted, neglecting pupils with competencies in other disciplines e.g. sports, arts... among others. Graduates being churned out today have very limited hands-on experience and find it difficult to manoeuvre in the economy as they are only armed with theory. A new paradigm with emphasis on practical subjects is, indeed, welcome.

In support of the above, the Commission showed that children entered Early Childhood Education and Care centres at the tender age of between three and five years where they were prepared for academic literacy. At the age of six, they proceeded to doing seven years (Grade 1 to 7 ) of primary education. At this level, those children studied various disciplines, which included the examinable subjects of Mathematics, English Language, Content and an indigenous language, ChiShona or IsiNdebele. Although there was 
.... a considerable number of pupils [that] drop[ped] out of school at this level,... [the majority of them were allowed to enrol for a full-blooded academic course of study at the secondary level, which comprised] 2 years for Zimbabwe Junior Certificate (ZJC), 2 years for General Certificate of Education Ordinary level and 2 years for GCE Advanced level...Though the Ordinary level certificate is the school leaving certificate, a considerable number of pupils proceed to Advanced level, in order to prepare for entry into universities (CEIT: 240).

Existing side by side with the mainstream academic schools, albeit absorbing a small fraction of the school leavers, were various skills training centres, vocational and technical training colleges and polytechnics. A graphic summary of the preceding is given, in Figure 1 below.
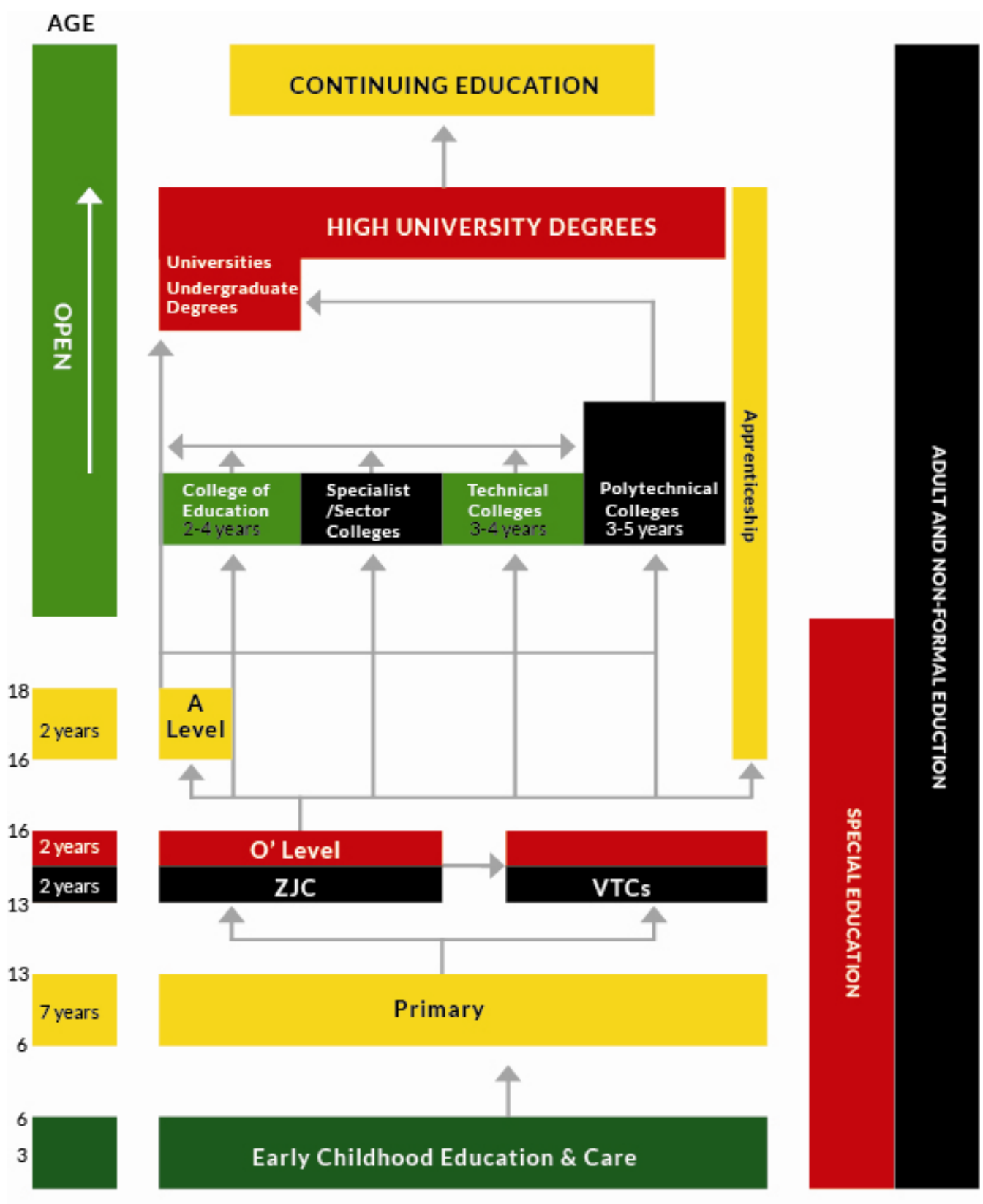

The sizes of the rectangular blocks do not represent the proportion of particpants

Figure 1. Zimbabwe Education System as Reported, in 1999

Source: CEIT (1999) Final Report, p. xxii. 
Having noted the apparent shortcomings of the Zimbabwean school system and, in line with the Third Millennium educational vision of Zimbabweans and the United Nations Educational, Scientific, and Cultural Organisation (UNESCO), CEIT recommended an outcomes-based national curriculum with provision for an innovative 'Four-Pathway' approach to the development of vocational and technical skills among students. It was hoped that such a skills-driven education would enable young Zimbabweans, to not only create their own employment, but also work effectively, in industry where "work-related competencies, such as problem-solving, use of technology and organisational skills," are critically considered to be important (CEIT, 1999: 243). The full details of the new school system for Zimbabwe that CEIT proposed are shown hereunder:
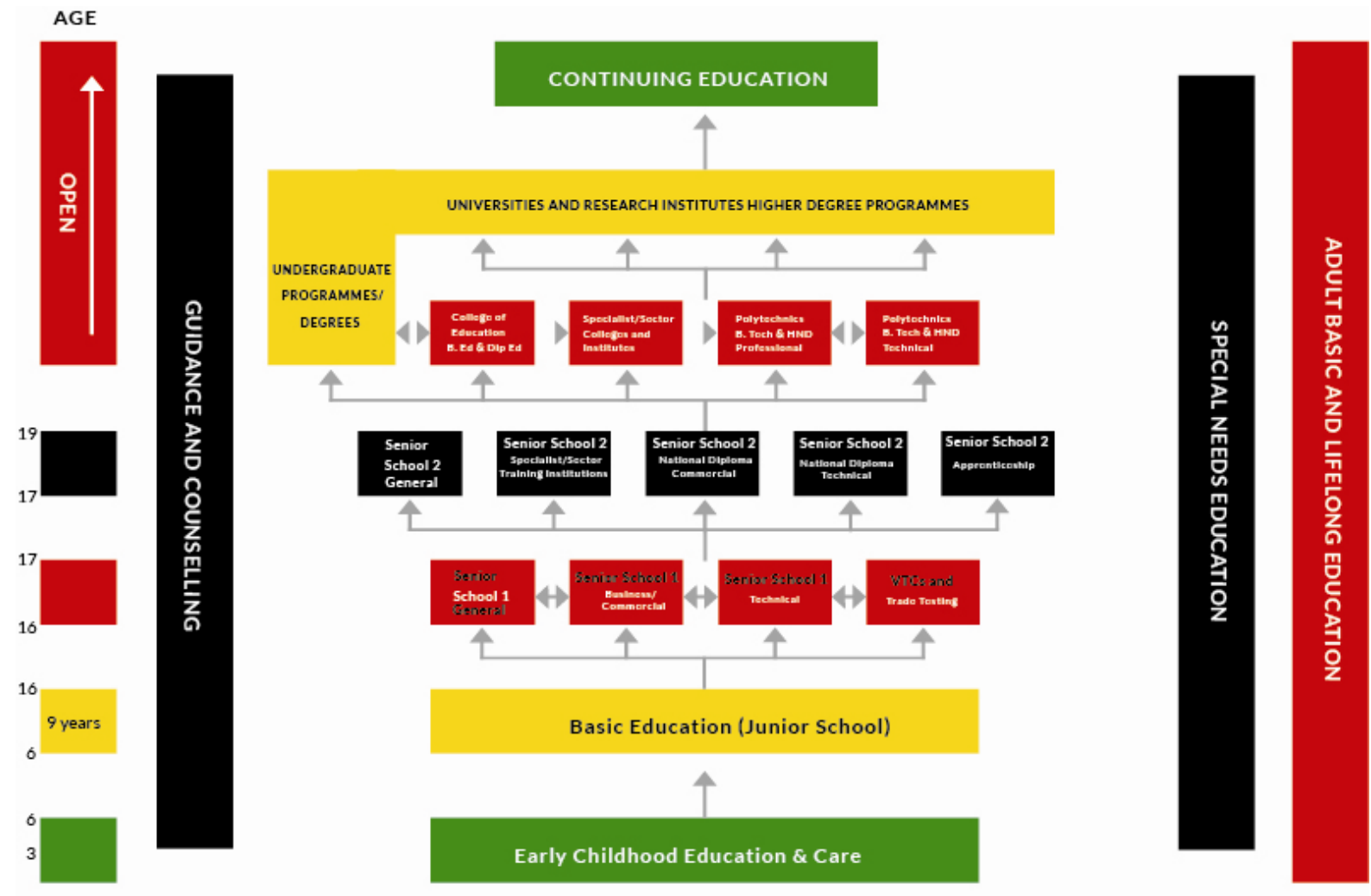

The sizes of the rectangular blocks do not represent the proportion of particpants

Figure 2. The Proposed Zimbabwe Education Structure

Source: CEIT (1999) Final Report, p. 248.

As regards the new educational structure, the development of all-round basic skills encompassing manipulative, computer, mathematical, civic, scientific, social, and linguistic skills among pupils was to take place at the junior school level (Grade 1 to 9) (Nziramasanga, 2014). At the senior school levels, 1 and 2, students would choose from four proposed learning tracks, General (academic), Business/commercial, technical, and vocational to further develop those skills. The university was considered the highest possible level for the refinement and further research on the skills, in question.

The CEIT's report, possessing well over 239 recommendations, was officially presented to His Excellency, the President and Commander-in-Chief of the Defence Forces of the Republic of Zimbabwe, in August 1999. After it had been fine-tuned to accommodate the tastes of the major stakeholders, the report was finally adopted by both Cabinet and Parliament and was set for implementation, in the year 2000. Regrettably, more than a decade elapsed before the new school system was put, in place. It seemed that the Government did not have adequate financial resources needed to reform the system, in such a radical way. Howsoever, in March 2012, the Government presented, to the nation, the 'Second Science, Technology and Innovation Policy', which recognised the criticality of science and technology, in the Industrialisation of the country. Thus, it shifted its focus away from vocationalising state-controlled schools. Consequently, the Ministries of Primary and Secondary Education; and that of Higher and 
Tertiary Education, Science and Technology Development, were challenged, "to re-align their training programmes in order to produce cadres, in sufficient quantities and high quality, to effectively translate the Policy into practical actions for concrete outputs and outcomes" (Tsvangirai, in Government of Zimbabwe, 2012: vii). Hence the origin of the school curricular innovation, STEM.

\subsection{The Science, Technology, Engineering and Mathematics (STEM) Project}

Following the Presidential speech that was delivered, in 2013, which underscored “...the need to equip learners with knowledge, skills and values that guarantee economic growth and increased opportunities for employment creation, well-rounded citizens who are relevant nationally and competitive globally", the Ministry of Primary and Secondary Education was forced to re-think the national school curriculum (Mberi and Phambili, 2016: 12). The ministry subsequently undertook an update review of the aforesaid curriculum, in October 2014, which resulted, in the production of the 'Zimbabwe Curriculum Blueprint (2015-2022). The education reform plan is designed to:

[P]romote...a competency-based approach, which is realised through practical-oriented learning and other strategies. It is envisaged that the curriculum will shift from a content-based curriculum, which focuses on knowledge acquisition, to a competency-based curriculum, which focuses on learners' capacity to apply knowledge, skills and attitudes in an independent, practical and responsible way. This would mobilise the potential of Zimbabwean learners to compete successfully in the labour market locally and abroad. (Zimbabwe Ministry of Primary and Secondary Education, in Partnership with UNICEF (Undated: 10).

While recognising the centrality of STEM, in the new curriculum, the ministry, however, insists "that the Zimbabwe education system would have to temper the STEM disciplines with the Arts and heritage studies, resulting, in the STEAM disciplines (Science, Technology, Engineering, Arts, [and] Mathematics), becoming the drivers of the economy" (Zimbabwe Ministry of Primary and Secondary Education, in Partnership with UNICEF (Undated: 14). In addition, the ministry incorporated, into the new curriculum, the philosophy of 'Unhuism/Ubuntuism', which defines the peculiarity of the Zimbabwean cultural identity. It is argued that the country's citizens who are unable to exhibit "values such as good citizenship, integrity, fairness and respect for life, property and labour...would not satisfy national expectations with regard to development" (Zimbabwe Ministry of Primary and Secondary Education, in Partnership with UNICEF, undated: 14).

In marked contrast to the position of the Ministry of Primary and Secondary Education, the Ministry of Higher and Tertiary Education, Science and Technology Development sees STEM rather than STEAM as the panacea for the economic challenges facing the country. Think tanks within this ministry are decidedly convinced that STEM provides the optimum environment for the development of invaluable competencies such as "problem solving, critical thinking, creativity, team work, communication skills and conflict resolution" Ministry of Higher and Tertiary Education, Science and Technology Development (2016: 5). Skills, such as these, are deemed to be of crucial importance for the socio-economic transformation of the country and should, therefore, be developed among students. Hence

The ultimate objective of the STEM revolution would be to position Zimbabwe as a global leader in scientific discoveries and technological breakthroughs and effective exploitation of economic prospects from commercialisation of research results enhancing her competitiveness (Ministry of Higher and Tertiary Education, Science and Technology Development (2016: 5).

The economic slogans: "STEMITISATION for addressing social and national economic challenges" and "IF WE STEMITISE, WE INDUSTRIALISE" presently appearing on the roadside billboards of the Harare Polytechnic and the Zimbabwe Manpower Development Fund (ZIMDEF) respectively, testify to the above assertion that "the study of STEM subjects will result in the industrialisation of the economy and will also create employment" (Mberi and Phambili (2016: 12). The institutions cited above are affiliated to the Ministry of Higher and Tertiary Education, Science and Technology Development.

In a bid to achieve the objectives of STEM, "the Government, [according to Ncube, (2016: 5)] rolled out [the programme] through the Ministry of Higher and Tertiary Education, Science and Technology Development." The project encourages "pupils who took their Ordinary Level examinations in 2015 and attained grade "C" or better in Mathematics, Biology, Physics and Chemistry to take a combination of STEM subjects at "A" Level" (Mberi and Phambili, 2016: 12). The move was born out of the realisation that there was a noticeable decline, in the candidature of pupils who took pure sciences at "A" level

...leading to low enrolments in STEM at University level. It is estimated that less than $17 \%$ of the total enrolment in Zimbabwean Universities are in STEM related disciplines with the majority being in commerce and social sciences- 
a situation that cannot adequately support the value addition and beneficiation of our natural resources in order to effectively extend product value chain as the nation prepares for our envisaged national knowledge economy (Ministry of Higher and Tertiary Education, Science and Technology Development, 2016: 2-3).

The relevant supporting statistical data are given as follows:

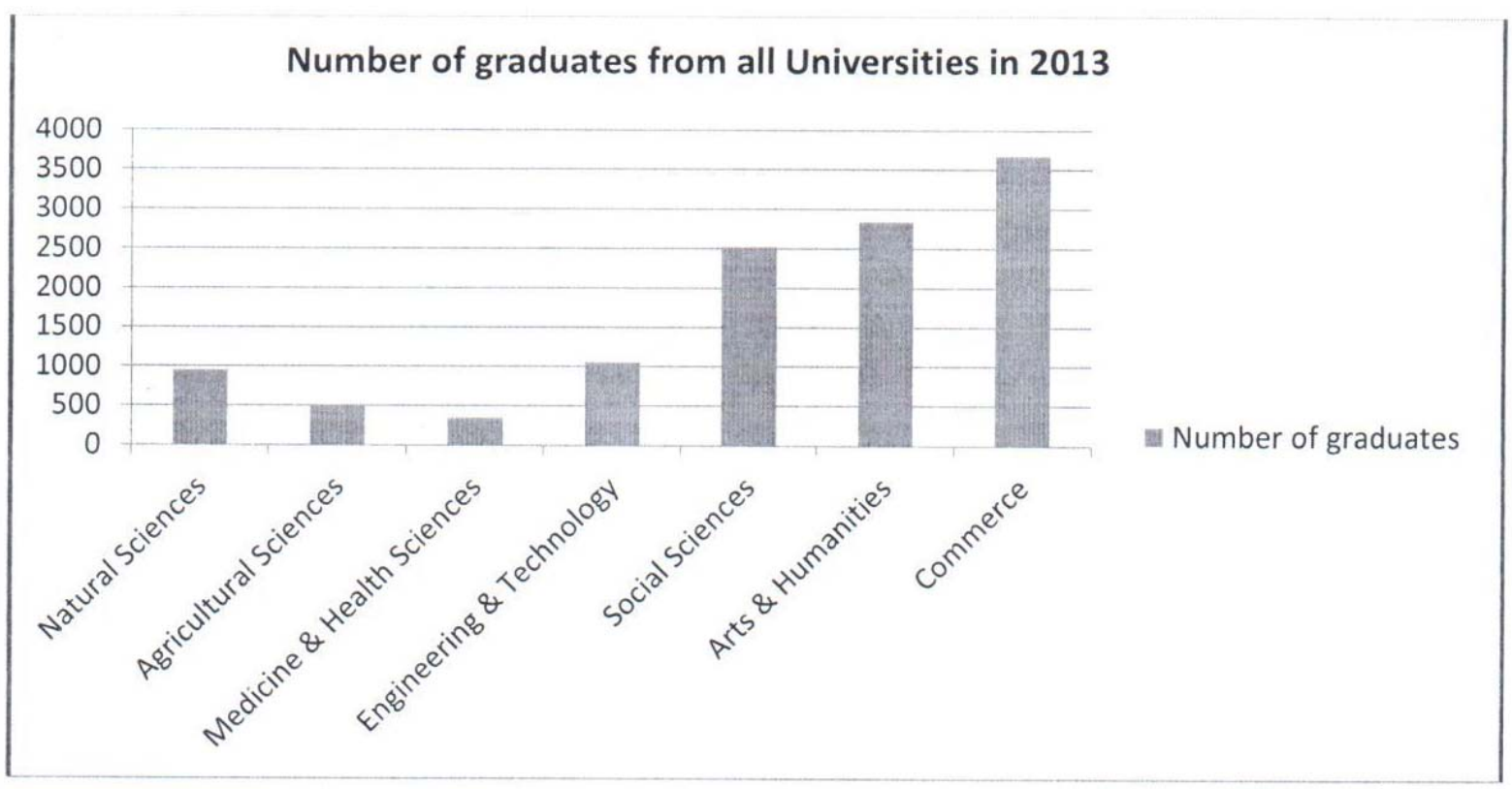

Figure 3. The Number of Graduates from All Universities, in 2013

Source: Ministry of Higher and Tertiary Education, Science and Technology Development (2016: 3).

From the point of view of the Ministry of Higher and Tertiary Education, Science and Technology Development, the STEM project is, therefore, designed to:

1. Increase the number of STEM students who will enrol on STEM degree programmes at the country's universities, in 2018 [and beyond];

2. Promote STEM careers, in response to Zim Asset's human capital objectives;

3. Develop STEM skills that are critically needed for the country's new industrialisation thrust;

4. Address the problem of unemployment; and

5. Empower young people through the promotion of science and innovation (Mberi and Phambili, 2016: 12).

The innovative STEM project has been positively received by parents and students alike as evidenced by the enrolment figures recorded to date. According to Katongomara (2016), more than 4000 students have, so far, registered for the programme. This number includes some pupils from schools, in the remotest parts of the country. As a symbolic gesture of support, "the government is paying full school and boarding fees for all excelling pupils who register for STEM subjects at public schools at Advanced Level this year through a grant of \$4 million set aside from the Zimbabwe Manpower Development Fund [ZIMDEF]" (Ncube, 2016: 5). As at the end of March 2016, about $\$ 1$ million had been paid for those students (Katongomara, 2016). Up until now, the innovation has been, in the full glare of media publicity owing to the ministry's aggressive marketing campaign strategy. Mberi and Phambili (2016:12) report:

As part of the efforts to encourage schools and students to take up STEM, high schools that register full Lower Six STEM classes this year will stand a chance to win a state-of-the-art STEM bus and a cash prize of \$1 000,00 [courtesy of the Ministry Higher and Tertiary Education, Science and Technology Development. Further,] Lower Six students who register for STEM subjects in 2016 will stand a chance to win a lifetime trip to Microsoft and other Silicon Valley STEM companies, in the United States of America... 10 winners will travel to the United States while 100 winners will walk away with a state-of-the-art laptop. The same number of winners will also get state-of-the-art iPads. 
However, the question of especial importance one may ask is:

\subsection{What Are the Potential Challenges, Prospects and Benefits of the STEM Project?}

As was noted earlier, there seems to be policy dissonance, in the two ministries of education regarding the disciplines that should be studied, in order to industrialise the country. The Ministry of Primary and Secondary Education is emphasising Science, Technology, Engineering, the Arts, Heritage Studies and Mathematics minus Commercial subjects (STEAM), while that of Higher and Tertiary Education, Science and Technology Development has settled for Science, Technology, Engineering and Mathematics (STEM) minus the Arts and Commercials. There is, therefore, the potential danger of the two ministries working at cross purposes. Thus helping, in no way, to allay fears expressed initially by Madhuku (2015: 11): "Desired results cannot be achieved, in this exercise if these two ministries [do not] work, in liaison with each other because of their interconnectedness or [inseparability], in terms of the envisaged curriculum innovations." Perhaps the treatment of certain subjects as the paradigm of human knowledge is unfortunate. For, it seems persuasive that all contrived disciplines are lenses through, which reality can be understood. What Zimbabwe, therefore, needs are critical, innovative thinkers of different specialism who can make a meaningful contribution to the complete socio-economic transformation of the country.

Another potential challenge that is likely to impede the successful implementation of the innovation is the existence, at present, of a serious shortage of suitably qualified science teachers, in Zimbabwe. According to a report written by Ncube (2016: 5) ... "there is a shortage of 1521 Science and Mathematics teachers, in the country due to brain drain." The majority of those teachers have signed lucrative contracts with education authorities, in some of the SADC regional countries and are, therefore, reluctant to come back home. Meanwhile, the Ministry of Primary and Secondary Education (MoPSE) has assured the nation that "there will be enough teachers, proficient with the new palate of the curriculum” (Mukondiwa, 2015: 13). “There is capacity building going on as we speak, even among line managers. In fact, 2,500 teachers have been enrolled, so far, to equip them with the tools to bring about the positive change of the curriculum. Their retention is crucial” (Dokora in Mukondiwa, 2015: 13). But, according to Chitamba, (2015: 21):

[S]taff development is not taking place in a way or at a rate at which it is supposed due to two main factors, among others. Firstly, there is resistance among some of the qualified teachers (those with professional teaching qualifications) and semi-qualified teachers (graduates and others with non-teaching qualifications) to undergo training to upgrade their qualifications and acquire professional/teaching qualifications respectively. Secondary, both qualified and semi-qualified teachers are finding it difficult to further and upgrade their qualifications due to financial constraints owing to the high fees demanded by colleges and universities, against the current economic quagmire.

Therefore, the perennial shortage of skilled teachers at the chalk-face of STEM classrooms is very likely to prevent the full realisation of the project's assessment objectives.

Learning facilities are, as well, limited, most particularly, in the new resettlement areas created by the on-going historic land reform programme that began, in 2000. The attempt to redress the colonial land imbalance has seen the former white "[f]arm houses and tobacco barns ... [being] converted to approximately 1, 500 satellite schools. The learning environment, in such schools is deplorable and is not compatible with the dawning curriculum” (Chere, 2015: 7). The teaching of the natural sciences is, especially hampered by the apparent lack of basic laboratory equipment, in both the new and old schools. Again, there is need for a constant review of curriculum content, which appears to be narrow. Hence the clarion call: "The post-independence STEM infrastructure, content/curriculum and instruction tools require urgent attention and strengthening” (Ministry of Higher and Tertiary Education, Science and Technology Development, 2016: 3). The authorities need to take heed of that call because relevant source documents show that many of the curricular change projects that have been attempted, in developing countries collapsed at the shoals of implementation largely due to the lack of facilities, relevant materials and other critical variables that may be brought to bear. An enabling implementation environment is, therefore, needed, in order to increase chances of the STEM project succeeding.

Nevertheless, the prospect of the project appears bright. The massive support that the innovation has received from some stakeholders is encouraging. Already, a private company, Gwango Elephant Lodge, in Hwange District, in the Matabeleland North Province of the country has openly embraced the project. The company is reported to have launched a Gwango STEM Initiative (GSI), in the area, which according to Ncube, (2016: 5)... “is a rapid results project supporting the Zimbabwe Agenda for Sustainable Socio-Economic Transformation (Zim Asset).” GSI is concerned with conducting 'career pathway' events with students and soliciting for scholarships and educational material. Most exciting perhaps is the arrangement to 
...have two Form 1 pupils, a boy and a girl, being selected from each participating school to participate in the prestigious GSI Scholars' Programme each year. They will receive intensive supplementary STEM education throughout the year. A world-class laboratory accessible to all GSI Scholars will be established in the district (Pasalt in Ncube, 2016: 5).

GSI is a classic example of the creation of Private-Public-Partnerships (PPPs)-one of the factors, which the Government considers to be critical, in the successful implementation of Zim Asset.

\section{Summary}

This short paper has shown that education, in the post-Independence Zimbabwe has a long, proud pedigree. The high position that the country enjoys, in the literacy scale, in Africa today bears testimony. However, the search for a 'worthwhile work-oriented curriculum' by the country's education planners has been relentless. This is evidenced by their latest and most influential attempt at 'stemitising' the nation's high school curriculum. That strategic initiative is meant to empower school leavers with employable skills relevant to the $21^{\text {st }}$ Century. Its success will depend on two main factors: Firstly, the much needed unity of purpose among key stakeholders, notably the two Ministries of Primary and Secondary Education and Higher and Tertiary Education, Science and Technology Development. And secondly, the availability of adequate human and material resources. An enabling implementation environment, is therefore, needed if the STEM objectives are to be realised.

\section{Conclusion}

Zimbabweans can take solace, in Fafuna's useful advice, in Olu (1996: 17): [People] "must be willing to experiment and not be afraid of failure if [their] country is to become self-reliant, self-assertive and self-confident." For, socio-economic development is a process, which has its ups and downs. Therefore, it requires everyone to take up a dogged-determination, in order to succeed.

\section{References}

Chere, R. (2015). Towards Smooth Implementation of the New Curriculum. Teacher in Zimbabwe, $3,7$.

Chitamba, J. (2015). 140, 000 Teachers. Preparing Today's Teachers for Tomorrow: Staff Development for the New Curriculum. Teacher in Zimbabwe, 3, 20-22.

Government of Zimbabwe (2013). Zimbabwe Agenda for Socio-Economic Transformation (Zim-Asset): Towards an Empowered Society and a Growing Economy, (October 2013-December 2018). Harare: Government Printers.

Katongomara, A. (2016). Ministry in last call for STEM funding hopefuls. The Chronicle, Tuesday, 29 March. Buluwayo: Government Printers.

Madhuku, J. (2015). Curriculum Review. Teacher in Zimbabwe, 3, 14-15.

Mberi, N., \& Phambili, M. (2016). Science, Technology, Engineering and Mathematics Craze hits Zimbabwe. The Sunday News: STEM Supplement, 28 February-5 March, 12.

Ministry of Higher and Tertiary Education, Science and Technology Development (2016) Concept Note (revised 13 January, 2016). Paper Presented at the $1^{\text {st }}$ National Conference on Science, Technology, Engineering and Mathematics (STEM) at Harare International Conference Centre from 28-28 January. Harare: Zimbabwe.

Mugabe, R. G. (2013). Foreword.' In Government of Zimbabwe (2013) Zimbabwe Agenda for Sustainable Socio-Economic Transformation (Zim Asset): Towards an Empowered Society and a Growing Economy (October 2013-December 2018). Harare: Government Printers.

Mukondiwa, R. (2015). It’S A Marathon, Not A Sprint! Teacher in Zimbabwe, 3, 12-13.

Ncube, L. (2016). Gwango Lodge joins STEM bandwagon. The Chronicle: Feature/Opinion, Tuesday, 1 March. Buluwayo: Government Printers.

Ngwawi, J. (2015). Regional Integration: SADC develops industrial strategy. Southern Africa Today, 17(3), 1-2.

Nziramasanga, C. T. (1999). The Presidential Commission of Inquiry into Education and Training (CEIT) Final Report. Harare: Government Printers.

Nziramasanga, C. T. (2014). The 1999 Presidential Commission of Inquiry into Education and Training (CEIT) Report: Implementation Enigmas or Revelations?’ In Madondo, M. M., Museka, G. and Phiri, M. (2014) (Eds.). 
The Presidential Commission of Inquiry into Education and Training (CEIT): Implementation Successes, Challenges and Opportunities. Harare: The Human Resources Research Centre, University of Zimbabwe.

Olu, A. (1996). Localization of Business and Technical Examinations in Nigeria: Challenges, Benefits and Prospects. In Zimbabwe School Examinations Council (ZIMSEC) Papers of the $14^{\text {th }}$ Annual Conference: Association for Educational Assessment in Africa (AEAA). Harare: Zimbabwe.

SARDC (2015). Prospects for Industrial Transformation in SADC: Towards a Regional Strategy and Roadmap. Harare: Southern Africa Research and Documentation Centre.

Tsvangirai, M. R. (2012). 'Foreword.' In Government of Zimbabwe (2012) Second Science, Technology and Innovation Policy of Zimbabwe. Harare: Government Printers.

Zimbabwe Ministry of Primary and Secondary Education, in Partnership with UNICEF (Undated) Zimbabwe Curriculum Blueprint (2015-2022). Harare: Government Printers. 